\title{
Vocational High School Students' Perceptions of Success in Mathematics
}

\author{
Huseyin Ozdemir ${ }^{\mathrm{a}}$ and Neslihan Onder-Ozdemir ${ }^{\mathrm{b}}$
}

\begin{abstract}
aHurriyet Vocational and Technical High School, Bursa, TURKEY; ${ }^{\text {TThe University of }}$
\end{abstract} Sheffield, Sheffield, UNITED KINGDOM

\begin{abstract}
Knowledge of mathematics is significant for each society because mathematics "acts as a 'gatekeeper' to social progress" (Gates \& Vistro-Yu, 2003, p. 32) and also a gateway for a good profession. The Programme for International Student Assessment (PISA) 2015 was completed by approximately 540,000 15-year-old students and published in 2016 PISA report. The 2016 PISA report showed that among 72 countries and economies, Turkey lagged behind most of the countries, i.e., 49th in mathematics, 52nd in science and 50th in reading. Given the state of Turkey, the problems in education should be scrutinised across subjects, including maths. To address this apparent proven problem, we conducted research on vocational high school students (i.e., mostly disadvantaged students). To the best of our knowledge, Turkish students' perceptions of success in mathematics who are studying in a vocational high school are under-researched. In light of this gap, the present longitudinal study sets out to investigate Turkish Vocational and Technical High School students' perceptions as learners of mathematics to contribute to the literature $(n=165)$. Open-ended questions were asked whether students believe that they are successful or unsuccessful and the underlying reasons why. The data were collected through a faceto-face structured interview and classroom observation. Among 165 vocational high school students, 61 of them believed that they were successful, 93 believed that they were unsuccessful and 11 students were hesitant. Reasons why students believed they are successful or unsuccessful were collected under five salient themes as follows: (i) reasons arising from students themselves; (ii) reasons arising from students' perceptions of maths course//their maths abilities, (iii) reasons arising from maths teacher, (iv) reasons arising from students' educational background, (v) reasons arising from the milieu.
\end{abstract}

KEYWORDS

Success in mathematics, vocational education, vocational students
ARTICLE HISTORY

Received 15 September 2016 Revised 10 November 2016 Accepted 22 February 2017

\section{Introduction}

Given the significance of mathematics knowledge in education and for the society, a number of studies across countries were conducted to provide new

\section{CORRESPONDENCE Huseyin Ozdemir $\square$ ozdemirmaths@gmail.com}

(C) 2017 H. Ozdemir and N. Onder-Ozdemir

Open Access terms of the Creative Commons Attribution 4.0 International License apply. The license permits unrestricted use, distribution, and reproduction in any medium, on the condition that users give exact credit to the original author(s) and the source, provide a link to the Creative Commons license, and indicate if they made any changes. (http://creativecommons.org/licenses/by/4.0/) 
insights into mathematics education as exemplified: The link between achievement in mathematics and socioeconomic status (Lubienski, 2000), perceived usefulness of mathematics (Stanic \& Hart, 1995), raising the awareness about the importance of mathematics (Mohr, 2008), confidence and perception regarding mathematics and learning (Saunders, 2005), gender and mathematics experience (Odell \& Schumacher, 1998), low percentage of students specializing in math and science (Hannover \& Kessels, 2004), objectives and standards of curriculum vocational high schools in Turkey (Aytaş et. al., 2000) and scales assessing task orientation (i.e., the beliefs that success in mathematics is fostered by effort, attempts to make sense of things, and cooperation with one's peers) and ego orientation (i.e., the beliefs that success depends on superior ability and attempts to beat other) to six second- grade classes (Nicholls et al., 1990).

Given that the present study set out to find out vocational high school students' perceptions of success in maths, we will review relevant empirical studies to contextualise the present research. In a comprehensive study, Carlson (1999) investigated the mathematical behaviour of six graduate students and the experiences that contributed to their mathematical development and success. She used a survey to find out students' beliefs and also used complex mathematical tasks to observe students' problem-solving behaviour. The findings indicated that a mentor, mostly a high school teacher, helped their problem-solving abilities and continued mathematical study. For example, in the interview, one student reported that "high school teacher had made math interesting and had taught her how to think mathematically, study for exams, and read mathematical text" (p. 244). Three of the students admitted that they had low motivation. The teachers in high schools encouraged the students to deal with the difficulty problems. It is also notable that whenever students encountered unfamiliar questions, they were persistent to handle with high confidence. They spent large amounts of time working mathematics problems. Carlson (1999) suggested that these non-cognitive factors have a significant role in a student's mathematical success. The study also shows the effect of the mathematics teacher in the high school education.

Ozgen and Bindak (2011) explored self-efficacy beliefs of high school students towards math literacy on 712 high school students using math literacy self-efficacy scale in Turkey. The findings revealed that significant differences in math literacy self-efficacy in terms of gender, school type, class level, math degree, parents' educational status and the importance given to math classes. Another dimension regarding findings was the significant effect of variables on math achievement and importance given to math classes for the math literacy self-efficacy. Also, high school students were "indecisive" about their math literacy and this shows that high school students have medium level belief in their Math Literate Self-Efficacy. As for students' self-efficacy beliefs, males had more positive results than females. This finding consisted with PISA 2003 study (OECD, 2004).

As Kloosterman and Stage (1992) pointed out "[b]eliefs do not change easily. Many students are quite content with the way they view mathematics and themselves as learners of mathematics" (p. 113). Among mathematics teachers, students' beliefs have been considered significant and received considerable attention in mathematics education (Garofalo, 1989; Schoenfeld, 1989; Leder et 
al., 2006). Kloosterman and Stage (1992) developed and validated Indiana Mathematics Scale to assess beliefs about mathematical problem solving with a criticism that researchers tend to use interviews and observations to measure students' beliefs in mathematics. They assessed five belief in their scale: (1) I can solve time-consuming mathematics problems, (2) There are word problems. They cannot be solved with simple, step-by-step procedures, (3) Understanding concepts is important in mathematics, (4) Word problems are important in mathematics and (5) Effort can increase mathematic ability. Kloosterman and Stage suggested that scales 2 and 4 measure belief about the discipline of mathematics and scales 1, 3 and 5 measure belief about the individual as a learner of mathematics.

A number of studies explored the mathematical belief of secondary and elementary students (e.g., Schoenfeld, 1989). However, little has been known regarding the specific belief, behaviour and abilities of vocational high school students in underdeveloped/developing countries like Turkey. Wolf (2011) states that vocational education involves courses that teach valuable skills to a very high standard. However, conventional academic education only partially meets the demands of the labour market. Thus, good vocational programmes are significant for education. Mane's (1999) research highlighted the need for vocational high school courses for American high school students to start their work life more successfully for steadier employment, higher wages and higher earnings. Mane's empirical findings were against closing down high school vocational education but calling for returning to high school vocational education. The findings suggest that high school students who are uncertain regarding college should choose an occupational category to develop skills before graduation from high school.

It is well-known that there are international assessments like PISA to identify schools that have high performance. PISA 2015 results showed that in some countries students are very successful in maths, i.e., Canada, Finland and Hong Kong (OECD, 2016), while there are also countries like Turkey where the success rate very low. For example, in PISA 2015, Turkey was ranked 49th in maths among 72 countries. Given this important problem in mathematics education, we aimed to investigate Turkish vocational high school students' perceptions as learners of mathematics to contribute to the literature because of the paucity of research on the vocational school setting.

In a comprehensive study, recently, there are attempts to associate vocational training with the needs of the society. Kiryakova et al., (2016) shared the social concern on the socio-economic conditions worldwide and the measures taken by industries, SMSs with the partnership with an aim to increase the effectiveness of vocational education. Also, they suggest that vocational education should prepare students for "true professionals, possessing high production and common culture, the ability and the desire to the development of technological and organizational innovations" (p. 458). In another study on vocational training, Kutueva et al., (2017) highlighted the "need to adapt vocational training to the needs of a modern economy" (p. 4). They aimed to develop practical guidance on the pedagogical monitoring in vocational education institutions. 500 teachers and 500 students took part in the study to identify criteria for effective implementation of the regional component of vocational education. 
Notably, in vocational schools, mathematics is crucial to be competent in the future professions of students who are studying in the vocational high schools. Rudduck and Flutter (2000) argued that we should look through the eyes of students if we want to make improvements in the school. The present study contributes to the studies on vocational education as discussed above to pave way for awareness on the vocational high school students' perceptions and belief to understand the context to enhance mathematics education.

To the best of our knowledge, the present study is the first research that addressed Turkish students' perceptions of success in mathematics who are studying in a vocational school through open-ended questions. Studies on mathematics education are not only in a global context but also in Turkey focused on primary school or high school mathematics education (e.g., Birgin et al., 2010; Bulut, 2007; Ozgen \& Bindak, 2011), and vocational high school students regarding their perceptions of success in mathematics remained little explored.

\section{Research Methods}

165 vocational high students in the $9^{\text {th }}, 10^{\text {th }}, 11^{\text {th }}$ and $12^{\text {th }}$ grades took part in the present study. The state vocational high school, where the first author currently teaching maths, consisted of disadvantaged students, i.e., many of the children from poor families or families with limited education and opportunities. Vocational students were not selected on the basis of an academic achievement or aptitude.

The data were collected during one year through face-to-face structured interviews with 165 students and classroom observation for triangulation of the data and to verify the findings in a Vocational and Technical High School in Turkey. Open-ended questions were asked whether students believe that they are successful or unsuccessful and the underlying reasons why. Content analysis was conducted to code the open-ended questions to find out the salient themes (Berelson, 1952; Weber, 1990).

\section{Results and Discussion}

When students' expressions were analysed, each student wrote at least three reasons and at most six reasons why they believed they were successful or unsuccessful in maths courses. Among 165 vocational high school students, 61 of them believed that they were successful, 93 believed that they were unsuccessful and 11 students were hesitant to answer as they stated that they believed they were sometimes successful but sometimes unsuccessful. The number of students who perceived themselves as successful in maths was fewer than the ones who perceived themselves as unsuccessful. We may attribute this finding to the fact that all the students who are at the last grade of the secondary school must take a placement examination in Turkey. According to the marks students receive, they are placed in high schools. In general, students who have the lowest mark tend to attend the vocational high schools. Given that the priority in the vocational schools is courses on vocational courses (see, Nogay, 2007); students are highly likely to be unsuccessful.

Content analysis showed the following five consistent salient themes regarding the reasons why students believed they were successful or unsuccessful: 
Reasons arising from

(i) students' perceptions of maths course/their maths abilities: This theme describes students' opinions about their maths ability, attitudes and feelings and self-assessment, thus, in contrast to themes one discussed above, they are more subjective. e.g., I am very good at numbers; I like solving maths questions; I am clever.

(ii) students themselves: This theme represents students' actions and behaviour regarding maths course.

(iii) students' educational background: Given that our target research group is vocational high school students, students stated that they educational background had an effect on their success in maths.

(iv) math teacher: This theme shows how maths teacher has an effect on students' learning

(v) milieu: The milieu seemed to have a little effect on the students' success and was limited with peer-assisted learning and also taking additional maths courses. Noisy or quiet classrooms could also be a factor for students' success.

46 of 93 low-achieving maths students reported that their bad educational background in maths is the underlying reason why they were unsuccessful, which is the most salient theme in our data. As we discussed above, vocational students have lower marks from placement examination to attend high school. This finding may also show a sign of the problems associated with maths education in primary and secondary school in Turkey that students experienced before coming to the vocational high school. Also, Das and Janzen's (2004) literature review outcomes suggest that being very successful in maths requires multiple cognitive processes, such as working memory and visual processing. They also add that if students have a solid understanding of basic maths concepts when they started education in the schools, they are highly likely to have maths competency.

The most salient theme why vocational students believed successful included the following reasons: 37 of 61 vocational students reported that they were successful because they like maths. This finding suggests that positive attitude towards a course is one of the most crucial aspects that should be taken into account for success. Thus, we tentatively deduce that maths teachers' role should create a scaffolding learning atmosphere in which students may have a positive attitude towards maths. All the reasons to be successful or unsuccessful arising from students' perceptions of maths course/their maths abilities were presented in Table 1.

Table 1. Reasons arising from students' perceptions of maths course/their maths abilities

\begin{tabular}{llc}
\hline I am successful in mathematics because... & 37 \\
\hline Reasons & I like maths. & 10 \\
arising from & Maths is easy. & 10 \\
students' & Maths is necessary for life and maths knowledge will be useful in & \\
perceptions of & the future. & 9 \\
maths & I can understand maths courses. & 8 \\
course/their & I am very good at numbers. & 8 \\
maths abilities & I have numerical intelligence. & 6
\end{tabular}


I like making operations in maths.

I am clever.

I become happy when I study maths.

Maths does not require memorisation.

I am patient.

\begin{tabular}{|c|c|c|}
\hline \multicolumn{3}{|c|}{ I am not successful in mathematics because... } \\
\hline \multirow{13}{*}{$\begin{array}{l}\text { Reasons } \\
\text { arising from } \\
\text { students' } \\
\text { perceptions of } \\
\text { maths } \\
\text { course/their } \\
\text { maths abilities }\end{array}$} & I have difficulty in understanding (some) topics in maths. & 41 \\
\hline & I do not like maths course. & 39 \\
\hline & I find maths course very boring. & 26 \\
\hline & I do not have interest in the course. & 20 \\
\hline & Maths course is difficult. & 20 \\
\hline & There are a lot of formulas in maths to memorise. & 17 \\
\hline & My numerical intelligence is poor. & 17 \\
\hline & $\begin{array}{l}\text { I get nervous in maths exams, so I cannot solve the questions } \\
\text { properly. }\end{array}$ & 11 \\
\hline & I think maths course is unnecessary and meaningless. & 7 \\
\hline & Topics in maths are complicated. & 6 \\
\hline & We do not use the topics we learn in maths for the real life. & 2 \\
\hline & I am not talented in maths. & 1 \\
\hline & I cannot do well in maths. & 1 \\
\hline
\end{tabular}

When we examine students' responses, who reported to believe they were unsuccessful in maths, 39 of 93 students stated that they did not like maths course, which is consistent with the study of Usul et al., (2007) and Hannula (2002). This finding is one of the most prominent views among students. An explanation for this finding may be the reason that the prejudice against maths and also a lack of guidance to deal with this important issue. Also, maybe because they are unsuccessful in maths, they do not like. The finding suggests revisiting maths teachers' role: Students should be encouraged by maths teachers and through activities in the curriculum to get rid of the prejudice they highlighted. We tentatively suggest that students' bad educational background may cause the bad perceptions they reported, such as difficulty in understanding (some) topics in maths $(n=41)$, finding maths course boring $(n=26)$, difficult $(n=20)$, unnecessary and meaningless $(n=7)$, complicated $(n=6)$ or feeling themselves as if they were not intelligent $(n=17)$ or not talented $(n=1)$.

Another important theme was reasons arising from students themselves. All the reasons to be successful or unsuccessful arising from students' themselves on maths course were presented in Table 2.

Table 2. Reasons arising from students' themselves on maths course

\begin{tabular}{lll}
\hline I am successful in mathematics because... & \\
\hline Reasons & I listen to maths courses very carefully and with attention. & 23 \\
arising from & I study maths regularly. & 17 \\
students & I revise topics we learn about maths at home. & 10 \\
themselves & I attend the courses actively. & 4 \\
& I do maths homework. & 3 \\
& I write the information, which is written on the board, to my & \\
& notebook in maths courses. & 1 \\
\hline
\end{tabular}




$\begin{array}{lll}\text { Reasons } & \text { I do not study maths. } & 40 \\ \text { arising from } & \text { I do not revise maths notes. } & 15 \\ \text { students } & \text { I listen to maths course. } & 12 \\ \text { themselves } & \text { I do not spare time to study maths. } & 9 \\ & \text { I attend the maths course without preparation. } & 1 \\ & \text { I do not ask my maths teacher the topics in maths that I do not } & 1 \\ & \text { understand. }\end{array}$

Students who believed they were successful in maths reported that they listened to the course very carefully and with attention $(n=23)$, they studied maths regularly $(n=17)$ and they revised topics that they had learned in maths courses $(n=10)$. Similarly, students who believed they were unsuccessful were aware of the close relation between not studying and unsuccessfulness. 40 students admitted that they were unsuccessful because they did not study maths. This finding suggests that students appear to take the responsibility to be unsuccessful.

The effect of the teachers on students' success in maths was another important response. This theme is consisted with the studies that sought to identify "good" and "bad" teachers (see Woods, 1990). Students focused on four aspects about how teacher affected their success. The most emphasized two responses were as follows: "Teacher teaches maths course very well" $(\mathrm{n}=30)$ and "I like the way my maths teacher is" ( $\mathrm{n}=17)$.

All the reasons to be successful or unsuccessful arising from teacher in maths course were presented in Table 3 .

Table 3. Reasons arising from teacher on maths course

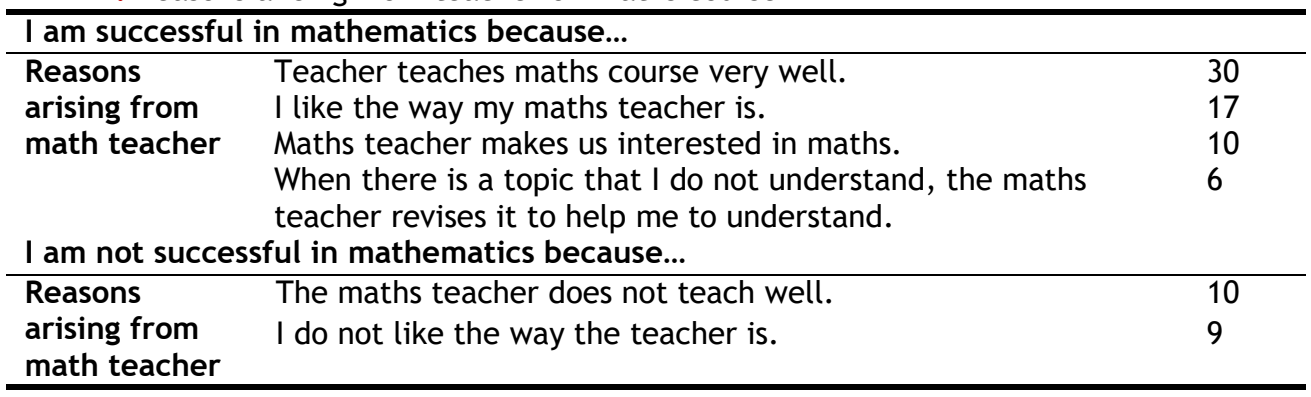

This finding is consistent with Carlson's (1999) study. Also, as Williams (2008) pointed out teachers have a big influence on students' attitudes towards maths and their mathematical skills. Interestingly, while students believed that teachers were very important for their success, only few students believed that they were unsuccessful in maths because of their maths teacher. The finding showed the effect of maths teacher's qualifications and personal characteristics. In light of this finding, we suggest that effective maths classrooms should be observed to describe the factors that math teachers have in vocational schools to draw a map to train maths teachers effectively.

According to the students, educational background, in other words the maths knowledge they gained from primary and secondary school, was the most 
important reason for not being successful $(n=46)$. All the reasons to be successful or unsuccessful arising from students' educational background on maths course were presented in Table 4.

Table 4. Reasons arising from students' educational background on maths course

\begin{tabular}{lll}
\hline I am successful in mathematics because... & 16 \\
\hline $\begin{array}{l}\text { Reasons arising } \\
\text { from students' } \\
\text { educational } \\
\text { background }\end{array}$ & \\
\hline I am not successful in mathematics because... & 46 \\
\hline $\begin{array}{l}\text { Reasons arising } \\
\text { from students' } \\
\text { educational } \\
\text { background }\end{array}$ & My background in maths is not good. \\
\hline
\end{tabular}

It is notable that students who believed that they were successful did not focus on educational background as much as students who believed they were unsuccessful $(\mathrm{n}=16)$.

The final theme was the milieu, which was expressed the least. The term milieu included the conditions and opportunities for students in classrooms, schools or their families. All the reasons to be successful or unsuccessful arising from the milieu were presented in Table 5.

Table 5. Reasons arising from the milieu

\begin{tabular}{lll}
\hline I am successful in mathematics because... & \\
\hline Reasons arising & My friends help me with my questions on maths problems. & 5 \\
\cline { 2 - 3 } from the milieu & I attend a private course/school extra courses for maths. & 5 \\
\cline { 2 - 3 } & In my family, there is a maths teacher. & 2 \\
\cline { 2 - 3 } & $\begin{array}{l}\text { Classroom is quiet in the maths class so I listen the course } \\
\text { carefully. }\end{array}$ & 2 \\
\hline \multirow{2}{*}{$\begin{array}{l}\text { I am not successful in mathematics because... } \\
\text { Reasons arising } \\
\text { from the milieu }\end{array}$} & The noise in the classroom & 13 \\
\cline { 2 - 3 } & The maths teacher change a lot. & 4 \\
\hline
\end{tabular}

\section{Pedagogical Implications for Maths Education: Educational Practices}

In the present research, we sought to elucidate vocational students' perceptions of success in maths in Turkish context. In line with our findings, we would like to provide some pedagogical implications to assess for effective maths teaching practices to be used in the mainstream classrooms. First, as our data revealed, there are various reasons that may have an effect on students' maths success. Thus, students' perceptions on achievement or failure in maths should be taken into consideration to find out how 'self-efficacy' affects students' success (Bandura, 1993).

Cooperation among stakeholders in education is necessary to create an effective teaching milieu, including administrative staff, maths teachers, students, parents), which may influence the practice of teachers. We suggest 
that a comprehensive needs analysis should be conducted to identify students' and maths teachers' needs to promote positive attitudes towards maths (see Kaufman \& English, 1979 for needs analysis). Integration of employing affective-humanistic approach to reach students (Weinstein \& Fantini, 1970) would be beneficial given that students in education are first a human being then a student. Finally, the math curriculum in the primary and secondary education should be improved before high education.

Future studies could be conducted to investigate successful maths teachers who achieve to reach students and to reveal the steps that are likely to pave a way for successful students in maths.

\section{Disclosure statement}

No potential conflict of interest was reported by the authors.

\section{Notes on contributors}

\section{References}

Aytaş, A., Panal, A., Türker, H. \& Oğulcu, F. (2000). Anadolu teknik liselerinde verilen eğitimin etkinliğinin değerlendirilmesi. Ankara: Mesleki ve Teknik Eğitim Araştırma ve Geliştirme Merkezi Başkanlığı.

Bandura, A. (1993). Perceived self-efficacy in cognitive development and functioning. Educational Psychologist, 28(2), 117-148.

Berelson, B. (1952). Content analysis in communication research. Education, 31(4), 454-482.

Birgin, O., Baloğlu, M., Çatlığlu, H. \& Gürbüz, R. (2010). An investigation of mathematics anxiety among sixth through eighth grade students in Turkey. Learning and Individual Differences, $20(6), 654-658$.

Borisovaa, O. V., Vasbievaa, D. G., Malykhb, N. I., Vasnevc, S. A. \& Vasnevad, N. N. (2017). Trends and Challenges in Development of Continuing Vocational Education and Training in Russia. IEJME, 12(1), 69-78.

Bulut, M. (2007). Curriculum reform in Turkey: A case of primary school mathematics curriculum. Eurasia Journal of Mathematics, Science \& Technology Education, 3(3), 203-212.

Carlson, M. P. (1999). The mathematical behavior of six successful mathematics graduate students: Influences leading to mathematical success. Educational Studies in Mathematics, 40(3), 237258

Das J. P. \& Janzen, C. (2004). Learning Math: Basic concepts, math difficulties and suggestions for intervention. Developmental Disabilities Bulletin, 32(2), 191- 205.

Garofalo, J. (1989). Beliefs, responses, and mathematics education: Observations from the back of the classroom. School Science and Mathematics, 89(6), 451-455.

Gates, P. \& Vistro-Yu, C. P. (2003). Is mathematics for all? In Second international handbook of mathematics education. Netherlands: Springer.

Hannover, B. \& Kessels, U. (2004). Self-to-prototype matching as a strategy for making academic choices. Why high school students do not like math and science. Learning and Instruction, 14(1), 51-67.

Hannula, M. S. (2002). Attitude towards mathematics: Emotions, expectations and values. Educational studies in Mathematics, 49(1), 25-46.

Kaufman, R. A., \& English, F. W. (1979). Needs assessment: Concept and application. Educational Technology, 14(2), 164-177.

Kiryakova, A. V., Tretiakovb, A. N., Kolgac, V. V., Piralovad, O. F. \& Dzhamalovae, B. B. (2016). Experimental Study of the Effectiveness of College Students' Vocational Training in Conditions of Social Partnership. IEJME, 11(3), 457-466.

Kloosterman, P. \& Stage, F. K. (1992). Measuring beliefs about mathematical problem solving. School Science and Mathematics, 92(3), 109-115. 
Kutueva, R. A., Mashkinb, N. A., Yevgrafovac, O. G., Morozovd, A. V., Zakharovae, A. N. \& Parkhaevf, V. T. (2017). Practical Recommendations on the Organization of Pedagogical Monitoring in Institutions of Vocational Education. IEJME, 12(1), 3-13.

Leder, G. C., Pehkonen, E. \& Törner, G. (2006). Beliefs: A hidden variable in mathematics education? New-York: Springer Science \& Business Media.

Longo, G. (1999). Mathematical intelligence, infinity and machines: beyond Godelitis. Journal of Consciousness Studies, 6(12), 191-214.

Lubienski, S. T. (2000). Problem solving as a means toward mathematics for all: An exploratory look through a class lens. Journal for Research in Mathematics, 15(2), 143-155.

Mane, F. (1999). Trends in the payoff to academic and occupation-specific skills: the short and medium run returns to academic and vocational high school courses for non-college-bound students. Economics of Education Review, 18(4), 417-437.

Mohr, C. (2008). Aligning classroom instruction with workplace skills: Equipping CTE students with the math skills necessary for entry-level carpentry. Techniques: Connecting Education and Careers, 83(8), 34-38.

Nicholls, J. G., Cobb, P., Wood, T., Yackel, E. \& Patashnick, M. (1990). Assessing students' theories of success in mathematics: Individual and classroom differences. Journal for Research in Mathematics Education, 21(2), 109-122.

Nogay, S. (2007). Türkiye'de meslek eğitimi sorunu ve çözüm önerisi. Ankara: Meslekî ve Teknik Ögretim Derneği Genel Merkezi.

Odell, P. \& Schumacher, P. (1998). Attitudes toward mathematics and predictors of college mathematics grades: Gender differences in a 4-Year business college. The Journal of Education for Business, 74(1), 34-38.

OECD. (2004). Learning for tomorrow's world - first results from PISA 2003. Paris: PISA OECD Publishing

OECD. (2016). PISA 2015 Results. Excellence and Equity in Education. Paris: PISA OECD Publishing

Ozgen, K., \& Bindak, R. (2011). Determination of Self-Efficacy Beliefs of High School Students towards Math Literacy. Educational Sciences: Theory and Practice, 11(2), 1085-1089.

Rudduck, J. \& Flutter, J. (2000) Pupil Participation and Pupil Perspective: 'carving a new order of experience". Cambridge Journal of Education, 30(1), 75-89.

Saunders, J. (2005). Gender and technology in education. A research review. The handbook of gender and education. London: Sage Publications.

Schoenfeld, A. H. (1989). Explorations of students' mathematical beliefs and behavior. Journal for Research in Mathematics Education, 3, 338-355.

Stanic, G. M. \& Hart, L. E. (1995). Attitudes, persistence, and mathematics achievement: Qualifying race and sex differences. New directions for equity in mathematics education, 2, 258-276.

Usul, H., Eroğlu, H. \& Akın, O. (2007). Meslek liseleri ve meslek yüksek okullarındaki eğitim süreçleri arasındaki uyum sorununun analizi ve ticaret lisesi örneği. Selçuk Üniversitesi Karaman İktisadi ve İdari Bilimler Fakültesi Dergisi, 12, 235-243.

Weber, R. P. (1990). Basic content analysis (No. 49). Sage. Weinstein, G. \& Fantini, M. D. (1970). Toward humanistic education: A curriculum of affect. London: Routledge.

Williams, P. (2008). Independent review of mathematics teaching in early years settings and primary schools: final report. London: DCSF publications.

Wolf, A. (2011). Review of vocational education: The Wolf report. Education, 17(3), 454-482.

Woods, P. (1990). The Happiest Days? How pupils cope with school. London: Falmer Press. 